\title{
The Influence of Ownership Structure and Income Management on Corporate Social Responsibility Disclosure
}

\author{
Fathimah F. Farhah \\ Student of Magister Management, Perbanas Institute \\ Jakarta, Indonesia
}

\author{
Iranti Safriyana \\ Perbanas Institute \\ Jakarta, Indonesia
}

\begin{abstract}
The purpose of this study is to provide evidence of the influence of managerial ownership, institutional ownership, foreign ownership, and earnings management of corporate social responsibility disclosure. The sample used was 15 companies with a purposive sampling method. The data used in this study uses secondary data in the form of annual financial reports and annual reports of manufacturing companies listed on the Indonesia Stock Exchange 2014-2017.

The study results found that managerial ownership, institutional ownership, and earnings management have no significant impact on corporate social responsibility disclosure. However, foreign ownership has a significant effect on corporate social responsibility disclosure.
\end{abstract}

Keywords:- Managerial Ownership; Institutional Ownership; Foreign Ownership; Earnings Management; Corporate Social Responsibility Disclosure.

\section{INTRODUCTION}

Recent research states that companies in Indonesia have a lower quality of corporate social responsibility (CSR) than companies from Thailand. A study from the Center for Governance, Institutions, and Organizations of the National University of Singapore (NUS) Business School explained that companies' poor understanding of CSR practices has resulted in the low quality of operating the plan. The research conducted 100 companies in four countries, namely Indonesia, Malaysia, Singapore, and Thailand. The study described Thailand is a country with the highest quality of CSR implementation with a score of 56.8 out of a total of 100, while Singapore got 48.8. Indonesia and Malaysia themselves scored 48.4 and 47.7 , respectively. The quality assessment criteria are based on several indicators from the Global Reporting Initiative (GRI) framework.

In the legal aspect, companies must comply with government regulations such as the Investment Law No. 25 of 2007 and the Limited Liability Company Law No. 40 of 2007, which requires the company to carry out CSR activities (Zarkasyi, 2008). Thus, CSR is an obligation that must be carried out by every company. In the legal aspect, companies must comply with government regulations. A comparison of the number of shareholders in the company existence arises due to the company's ownership structure. A company can be owned by an individual, the wider community, the government, foreign parties, or people in the company.

Company disclosure is usually carried out as necessary, considering the ownership is owned by insiders who can quickly obtain information about the company without exposure in the annual report concerning managerial ownership. Also, managerial ownership is a supervisory mechanism that aims to align various interests in the company. Institutional ownership is even thought to provide a similar supervisory means in companies as well as institutional ownership, generally acting as a party monitoring company. According to (Faizal, 2004), companies with broad institutional ownership indicate their ability to monitor similar institutional management. The more efficient the utilization of company assets is also to act as a prevention against waste by the company's management.

Most private investors do not have sufficient stock to influence company management. However, more and more company shares are being purchased by institutional investors. Because they control various resources, those investors, particularly mutual funds and pension funds, can buy large shares. (Ririn, 2011) theoretically stated that the higher institutional ownership and foreign ownership, the tighter supervision on company management to carry out and disclose corporate social activities. The company also conducts social information disclosure to build an image of the company and get public attention.

Continuing from previous research, analyzing the effect of ownership structure and earnings management on corporate social responsibility disclosure. The results showed that the relationship between ownership structure and CSR disclosure was re-tested. The existence of inconsistent results from previous studies makes this issue an essential topic to research. This research was conducted by (Rosamita, 2007). Researching the factors that influence the disclosure of a company's Corporate Social Responsibility concludes that: (1) simultaneous testing finds a significant influence between company factors on corporate CSR disclosure, (2) management ownership variables have a significant effect on social exposure.

In addition, further research that explores the relationship between CSR and earnings management, namely (Chih et al., 2008) suggests that managers generally tend to 
commit corruption through the implementation and disclosure of CSR by using advantages and benefits for consumption of opportunistic behavior. Companies that carry out CSR activities are expected to reduce the possibility of income smoothing.

\section{LITERATURE REVIEW}

Stakeholder theory states that the company's survival depends on the support of stakeholders who influence or can be influenced by the company's activities (Ghozali and Chariri, 2007). A research conducted by Roberts (1992) used stakeholder theory, namely stakeholder power, strategic posture, and economic performance related to corporate social disclosure. This indicates that investors' behavior as one of the users of financial statements can affect corporate social disclosure. On the contrary, investors in investing can use corporate social disclosure as a consideration in addition to using profits, which will affect the company's value.

According to Rawi and Munandar (2010), the Legitimacy theory states that organizations must continually try to ensure that they carry out activities by society's limitations and norms. Legitimacy can be a potential benefit or source for companies to survive (O'Donovan, 2002). Therefore, corporate social responsibility disclosure aims to show the public the company's social activities and their influence on society. The ultimate goal is none other than to support the company's primary purpose, such as to get maximum profit. This legitimacy will further enhance the company's reputation.

Corporate Social Responsibility is the company's commitment or the business world to contribute to sustainable economic development by paying attention to corporate social responsibility and emphasizing the balance between engagement to economic, social, and environmental aspects (Untung, 2008). Corporate Social Responsibility can be defined as a business commitment to contribute to sustainable economic development. Through collaboration with employees and company representatives, local communities, and the general public to improve the quality of life in ways that are beneficial for the continuity of the company's business and development (The World Business Council or Sustainable Development). So, CSR's purpose is a form of social concern for a company to serve the interests of the organization and the interests of the external public.

According to Rustiarini (2008), managerial ownership is a condition that indicates that the manager owns shares in the company, or the manager is also the shareholder of the company. Managerial ownership is a condition that means that the manager owns shares in the company, or the manager is also the shareholder of the company. Institutional ownership has an essential meaning in monitoring management because institutional ownership will encourage more optimal supervision (Sukarini, 2012). With the existence of institutional rights will enable increased supervision in management. Institutional ownership is the proportion of share ownership at the end of the year held by institutions, such as insurance, banks, or other institutions (Tarjo, 2008).

Foreign ownership is a party that is considered concerned about disclosure of corporate social responsibility. It is said that foreign share ownership is the number of shares owned by foreign parties (abroad) either by individuals or by institutions of company shares in Indonesia. Earnings management can be defined as company management's action to influence reported earnings to form information about economic advantages that the company does not experience. (Merchan and Rockness, 1994).

According to Tita and Wahdatul (2012), earnings management, board size, independent board of commissioners' porosity, managerial ownership, institutional ownership, and size of the audit committee had no impact on CSRD. The number of audit committee meetings has a positive impact on CSRD. Managerial ownership has no significant effect on CSR disclosure, institutional ownership does not substantially impact CSR disclosure, and foreign ownership has a significant impact on CSR disclosure (Rustiarini, 2008).

Research by Nasir and Abdullah (2004) showed that managerial ownership positively affects the relationship between managerial share ownership and the extent of CSR disclosure. According to Rosmasita (2007), the same thing found that managerial share ownership involves with CSR disclosure in Indonesia. Company managers will make decisions by the interests of the company, by disclosing the broadest possible social information to enhance the company's image even though they have to sacrifice resources for these activities (Anggraini, 2006). Based on these assumptions, the hypotheses that can be formulated are as follows:

\section{$>H_{1}$ : Managerial ownership has a significant effect on CSR.}

Institutional ownership can be used as an effort to improve the monitoring process. Institutional shareholders also have the opportunity, resources, and expertise to analyze management performance and actions. As owners, institutional investors are very interested in building a company's reputation (Mursalim, 2007). This study's results are supported by Djoko (2006), who found that institutional investors' investments do not significantly affect voluntary corporate disclosure in India. Based on these assumptions, the hypotheses that can be formulated are as follows:

\section{$>H_{2}$ : Institutional ownership has a significant effect on CSR.}

Disclosure of social responsibility is one of the media chosen to show the company's concern for the surrounding community. In other words, if the company has contracts with foreign stakeholders both in ownership and trade, the company will be more supported in disclosing social responsibility (Barkemeyer, 2007). Machmud and Chaerul (2008) proved that foreign ownership of public companies in Japan is a driving factor for adopting GRI in social 
responsibility disclosure. Based on these assumptions, the hypotheses that can be formulated are as follows:

\section{$>H_{3}$ : Foreign ownership has a significant effect on CSR.}

The research found by Lobo and Zhou (2001) states that one of the determinants to determine whether a company conducts earnings management is by looking at the company's disclosure policies. Policies that regulate the minimum requirements for disclosing information play an important role in the company's ability to manage its profits. Other studies that also support this study's results are (Chih et al., 2008). Also, research conducted by (Prior et al., 2010) states that earnings management positively affects CSR. Based on these assumptions, the formulation of hypotheses as follows:

\section{$>H_{4}$ : Earnings management has a significant effect on CSR.}

Managerial ownership, institutional ownership, foreign ownership, and earnings management affect CSR. It can be interpreted that if the variable managerial ownership, institutional ownership, foreign ownership, and earnings management increase, it will affect CSR.

$H_{5}$ : Managerial ownership, institutional ownership, foreign ownership, and earnings management have a simultaneous effect on CSR.

\section{METHODOLOGY}

The type of research used in this research is quantitative research with the analysis method of hypothesis testing. This study's scope only limits its discussion to examining whether managerial ownership, institutional ownership, foreign ownership, and earnings management affect corporate social responsibility disclosure. This study uses the CSR variable as the dependent variable, managerial ownership, institutional ownership, foreign ownership, and earnings management as independent variables.

This study took samples from manufacturing companies listed on the Indonesia Stock Exchange for the period 2014-2017. Sampling in this study was conducted using a purposive sampling method. Methods of data analysis in this study process the existing variables to produce a study and obtain conclusions using statistical tools as follows:

\section{$>$ Descriptive Statistical Analysis.}

The purpose of this descriptive analysis is to determine the ownership structure, earnings management, and disclosure of corporate social responsibility in manufacturing companies on the IDX. The analytical tool used is the average (mean), standard deviation, maximum, and minimum.

\section{Classical Assumption Test.}

This study's data analysis technique uses the normality test, multicollinearity test, heteroscedasticity test, and autocorrelation test.

\section{Multiple Regression Analysis.}

Hypothesis testing is carried out in a multivariate manner, using multiple regression. Multiple regression is used in this study because the independent variable is a combination of metric and nominal (non-metric) (Ghozali, 2007). Multiple regression is used to test whether the independent variables measured by management ownership (X1), institutional ownership (X2), foreign ownership (X3), and earnings management (X4) affect corporate social responsibility disclosure. The multiple regression model used to test the hypothesis is as follows:

$\mathrm{Y}=\alpha+\beta 1 \mathrm{X} 1+\beta 2 \mathrm{X} 2+\beta 3 \mathrm{X} 3+\beta 4 \mathrm{X} 4+\mathrm{e}$

\section{$>$ Determinant Coefficient Test.}

The coefficient of determination is expressed by $\mathrm{R}^{2}$, which measures how far the model can explain the variation in the independent variable. The coefficient of determination is between 0 and 1 . A small $R^{2}$ value means that the independent variable's ability to explain the dependent variable is limited. A value close to 1 means that the independent variable provides almost all the information needed to predict the dependent variable (Ghozali, 2007).

\section{Hypothesis Test.}

Parametric used if the distribution of data used is normal. Meanwhile, non-parametric used if the distribution of the data used is not normal. One type of parametric test is a regression test. To test the hypothesis proposed by the researcher, a simultaneous influence test (F test) and partial test (t-test) will be carried out.

\section{Partial Test.}

The $t$ statistical test shows how far the influence of one independent variable is partially explaining the dependent variable (Ghozali, 2007). If the probability of significance is much smaller than 0.05 , the independent variable partially affects the dependent variable.

\section{Simultaneous Effect Test.}

The $\mathrm{f}$ statistical test shows that all the independent variables referred to in the model have a simultaneous influence on the dependent variable (Ghozali, 2007). If the probability is much smaller than 0.05 , the regression model can simultaneously predict the independent variable against the dependent variable. 


\section{RESULTS}

\section{Descriptive Statisitical Analysis,}

\begin{tabular}{|l|r|r|r|r|r|}
\hline & $\mathrm{N}$ & Minimum & Maximum & Mean & $\begin{array}{c}\text { Std. } \\
\text { Deviation }\end{array}$ \\
\hline $\begin{array}{l}\text { Managerial } \\
\text { Ownership }\end{array}$ & 56 & .39 & 397.11 & 57.9576 & 93.07651 \\
\hline $\begin{array}{l}\text { Institutional } \\
\text { Ownership }\end{array}$ & 56 & .11 & 87.02 & 36.2896 & 25.87074 \\
$\begin{array}{l}\text { Foreign } \\
\text { Ownership }\end{array}$ & 56 & .50 & 8.14 & 3.9842 & 2.54460 \\
CSRD & 56 & 1.27 & 21.52 & 9.3128 & 5.48544 \\
\hline $\begin{array}{l}\text { Earning } \\
\text { Management }\end{array}$ & 56 & -33.48 & 20.35 & 1.2657 & 8.04138 \\
\hline Valid N (listwise) & 56 & & & & \\
\hline
\end{tabular}

Table 1:- Descriptive statistical test results (SPSS 25, 2019).

\section{Classical Assumption Test,}

Normal P.P Plot of Regression Standardized Residual

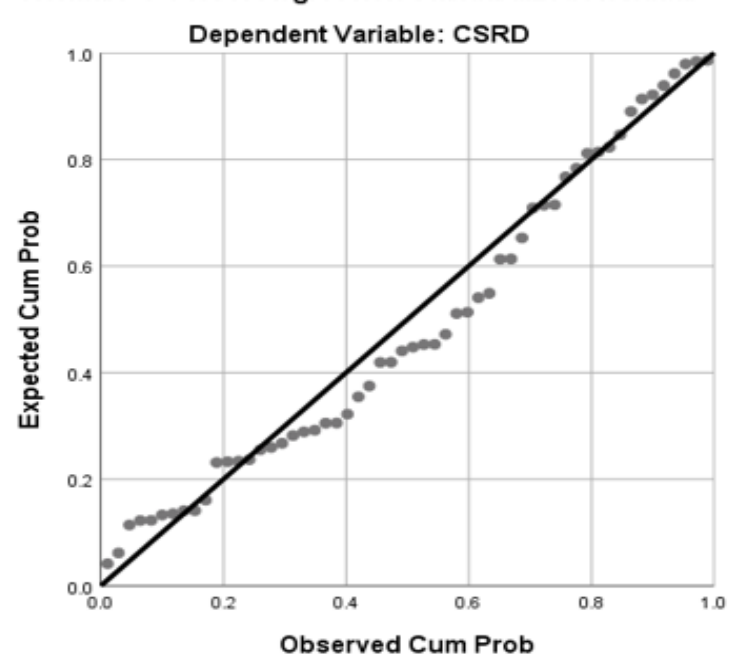

Fig 1:- The results of the data normality test (SPSS 25, 2019)

The normality test result is that the data spread around the diagonal line and follows the diagonal direction (Fig 1). It can be concluded that the data has a normal distribution.

\begin{tabular}{|c|c|c|c|}
\hline \multicolumn{4}{|c|}{ Coefficients $^{a}$} \\
\hline \multirow{2}{*}{\multicolumn{2}{|c|}{ Model }} & \multicolumn{2}{|c|}{ Collinearity Statistics } \\
\hline & & Tolerance & VIF \\
\hline \multirow[t]{4}{*}{1} & $\begin{array}{l}\text { Managerial } \\
\text { Ownership }\end{array}$ & .663 & 1.509 \\
\hline & $\begin{array}{l}\text { Institutional } \\
\text { Ownership }\end{array}$ & .222 & 4.509 \\
\hline & $\begin{array}{l}\text { Foreign } \\
\text { Ownership }\end{array}$ & .219 & 4.564 \\
\hline & $\begin{array}{l}\text { Earning } \\
\text { Management }\end{array}$ & .946 & 1.057 \\
\hline
\end{tabular}

a. Dependent Variable: CSRD

Table 2:- Multicollinearity test results (SPSS 25, 2019).
The table above shows that all independent variables have a tolerance value greater than 0.10 (Table 2), and a Variance Inflation Factor (VIF) value smaller than ten means that there is no correlation between the independent variables.

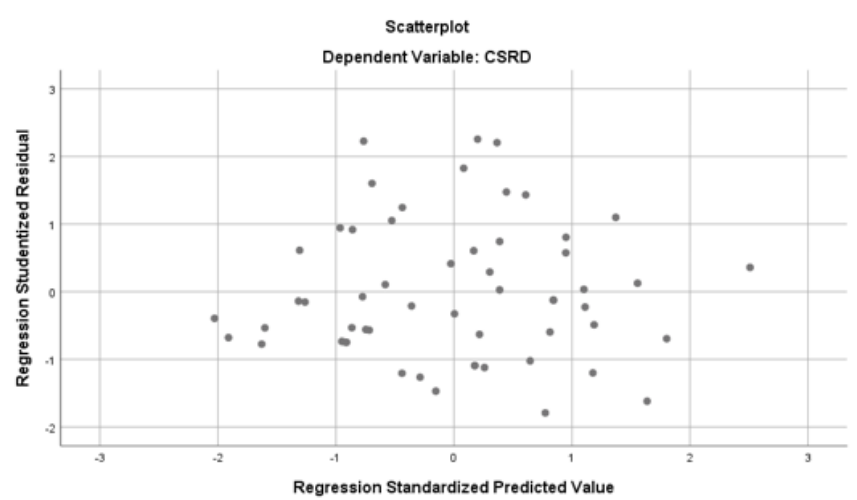

Fig 2:- Heteroscedasticity test results (SPSS 25, 2019).

Based on the results of the heteroscedasticity test in Figure 2, it can be seen that the dots spread above and below 0 and do not gather in one place and do not gather in one place and do not form a pattern, so it can be concluded that in this regression test, there is no heteroscedasticity problem.

\begin{tabular}{|l|c|r|r|r|c|}
\hline \multicolumn{7}{|c|}{ Model Summary b $^{\mathrm{b}}$} \\
\hline Model & $\mathrm{R}$ & $\mathrm{R}$ Square & $\begin{array}{c}\text { Adjusted R } \\
\text { Square }\end{array}$ & $\begin{array}{c}\text { Std. Error of } \\
\text { the Estimate }\end{array}$ & $\begin{array}{c}\text { Durbin- } \\
\text { Watson }\end{array}$ \\
\hline 1 & $.314^{\mathrm{a}}$ & .099 & .028 & 5.40751 & 1.753 \\
\hline
\end{tabular}

Table 3:- Autocorrelation test result (SPSS 25, 2019).

Based on the results of the autocorrelation test, the Durbin-Watson (D-W) value is 1.753 out of 56 samples with five variables. This means that the test results conclude that there is no autocorrelation.

\section{Multiple Regression Analysis}

\begin{tabular}{|c|c|c|c|c|c|c|}
\hline \multicolumn{7}{|c|}{ Coefficients $^{\mathbf{a}}$} \\
\hline & & \multicolumn{2}{|c|}{$\begin{array}{l}\text { Unstandardized } \\
\text { Coefficients }\end{array}$} & \multirow{2}{*}{$\begin{array}{c}\text { Standardized } \\
\text { Coefficients } \\
\text { Beta } \\
\end{array}$} & \multirow[b]{2}{*}{$\mathrm{T}$} & \multirow[b]{2}{*}{ Sig. } \\
\hline \multicolumn{2}{|c|}{ Model } & B & Std. Error & & & \\
\hline \multirow[t]{5}{*}{1} & (Constant) & 4.945 & 4.880 & & 1.013 & .316 \\
\hline & $\begin{array}{l}\text { Managerial } \\
\text { Ownership }\end{array}$ & .011 & .010 & .181 & 1.109 & .273 \\
\hline & $\begin{array}{l}\text { Institutional } \\
\text { Ownership }\end{array}$ & .076 & .060 & .359 & 1.272 & .209 \\
\hline & $\begin{array}{l}\text { Foreign } \\
\text { Ownership }\end{array}$ & .274 & .612 & .127 & .448 & .046 \\
\hline & $\begin{array}{l}\text { Earning } \\
\text { Management }\end{array}$ & -.083 & .093 & -.122 & -.894 & .375 \\
\hline
\end{tabular}

Table 4:- Multiple regression analysis result (SPSS 25, 2019). 
ISSN No:-2456-2165

Based on the results of the table above, the multiple regression model equation is obtained as follows:

$\mathrm{Y}=4,945+0,011$ Managerial Ownership $+0,076$ Institutional Ownership + 0,274 Foreign Ownership - 0,083 Earning Management $+\mathrm{e}$

\section{Determinant Coefficient Test,}

\begin{tabular}{|l|c|r|r|r|c|}
\hline \multicolumn{7}{|c|}{ Model Summary $^{\mathrm{b}}$} \\
\hline Model & \multicolumn{1}{|c|}{$\mathrm{R}$} & R Square & $\begin{array}{c}\text { Adjusted R } \\
\text { Square }\end{array}$ & $\begin{array}{c}\text { Std. Error of } \\
\text { the Estimate }\end{array}$ & $\begin{array}{r}\text { Durbin- } \\
\text { Watson }\end{array}$ \\
\hline 1 & $.314^{\mathrm{a}}$ & .099 & .028 & 5.40751 & 1.753 \\
\hline
\end{tabular}

Table 5:- Determinant coefficient test (SPSS 25, 2019).

Based on the results in table 5 , the $\mathrm{R}^{2}$ value is $9 \%$. This shows that the independent variables used in this study can predict CSR by $9 \%$, while the remaining $91 \%$ is predicted by other variables not used in this study.

\section{Partial Test}

\begin{tabular}{|c|c|c|c|c|c|c|}
\hline \multicolumn{7}{|c|}{ Coefficients $^{\mathrm{a}}$} \\
\hline & & \multicolumn{2}{|c|}{$\begin{array}{l}\text { Unstandardized } \\
\text { Coefficients }\end{array}$} & \multirow{2}{*}{$\begin{array}{l}\text { Standardized } \\
\text { Coefficients } \\
\text { Beta }\end{array}$} & \multirow[b]{2}{*}{$\mathrm{T}$} & \multirow[b]{2}{*}{ Sig. } \\
\hline \multicolumn{2}{|c|}{ Model } & B & Std. Error & & & \\
\hline \multirow[t]{5}{*}{1} & (Constant) & 4.945 & 4.880 & & 1.013 & .316 \\
\hline & $\begin{array}{l}\text { Managerial } \\
\text { Ownership }\end{array}$ & .011 & .010 & .181 & 1.109 & .273 \\
\hline & $\begin{array}{l}\text { Institutional } \\
\text { Ownership }\end{array}$ & .076 & .060 & .359 & 1.272 & .209 \\
\hline & $\begin{array}{l}\text { Foreign } \\
\text { Ownership }\end{array}$ & .274 & .612 & .127 & .448 & .046 \\
\hline & $\begin{array}{l}\text { Earning } \\
\text { Management }\end{array}$ & -.083 & .093 & -.122 & -.894 & .375 \\
\hline
\end{tabular}

a. Dependent Variable: CSRD

Table 6:- Partial test result (SPSS 25, 2019)

\section{Simultaneous Effect Test,}

Based on the results of the Simultaneous Effect Test (Test F), it can be seen that together the independent variables have a significant effect on the dependent variable. This can be proven by a significant value ( $\mathrm{sig}$ ) of 0.0001 . The significant value (sig) is less than 0.05 , it means that there is a simultaneous influence from the independent variable on the dependent variable. Namely, the simultaneous effect of Managerial Ownership $\left(X_{1}\right)$, Institutional Ownership $\left(X_{2}\right)$, Foreign Ownership $\left(\mathrm{X}_{3}\right)$, Earnings Management $\left(\mathrm{X}_{4}\right)$ affects CSR.

\begin{tabular}{|c|c|c|c|c|c|c|}
\hline \multicolumn{7}{|c|}{ ANOVA $^{a}$} \\
\hline \multicolumn{2}{|c|}{ Model } & $\begin{array}{l}\text { Sum of } \\
\text { Squares }\end{array}$ & Df & Mean Square & F & Sig. \\
\hline \multirow[t]{3}{*}{1} & Regression & 163.655 & 4 & 40.914 & 1.399 & $.000^{b}$ \\
\hline & Residual & 1491.300 & 51 & 29.241 & & \\
\hline & Total & 1654.955 & 55 & & & \\
\hline
\end{tabular}

a. Dependent Variable: CSRD

b. Predictors: (Constant), Earning Management, Managerial Ownership,

Institutional Ownership, Foreign Ownership

Table 7:- Simultaneous effect test result (SPSS 25, 2019)

\section{DISCUSSION}

\section{The Effect of Managerial Ownership on CSR,}

The partial test ( $\mathrm{t}$ statistical test) showed that Managerial Ownership has no significant effect on CSR. This study's results are consistent with the research (Ni Wayan, 2008), which shows that managerial ownership has no significant effect on CSR. However, this study's results are inconsistent with research (Nasir and Abdullah, 2004), which shows that managerial ownership has a significant effect on the relationship between managerial ownership and the extent of CSR disclosure. This is possible because, statistically, the average number of shares owned by managerial in Indonesian companies is relatively smaller. There is no alignment between the interests of owners and managers.

\section{The Effect of Institutional Ownership on CSR,}

The partial test (t statistical test) showed that institutional ownership has no significant effect on CSR. The results of this study are consistent with the research by (Ni Wayan, 2008) that institutional ownership does not have a significant effect on CSR. However, this study's results are inconsistent with research by (Anggraini, 2006) that institutional ownership has a significant effect on CSR. This is possible because institutional investors only aim to prioritize personal interests without caring about other stakeholders' responsibilities.

\section{The Influence of Foreign Ownership on CSR,}

The partial test (t statistical test) showed that foreign ownership has a significant effect on CSR. This study's results are consistent with the research (Ni Wayan, 2008), namely that foreign ownership has a significant effect on CSR. This makes it possible that, in general, foreign ownership in Indonesia is concerned about social issues such as human rights, education, labor and the environment as critical issues that must be disclosed in company annual reports.

\section{The Effect of Profit Management on CSR,}

The partial test (t statistical test) showed that earnings management has no significant effect on CSR. This study's results are consistent with research conducted by (Tita and Wahdatul, 2012) that earnings management has no significant effect on CSR. However, this study's results are not consistent with the research (Prior et al., 2007) that earnings management has a significant effect on CSR. According to (Chih et al., 2008), this allows for different 
management considerations in presenting their financial information.

\section{CONCLUSION}

This study is to determine the effect of Managerial Ownership, Institutional Ownership, Foreign Ownership and Earnings Management on Corporate Social Responsibility Disclosure. Based on the study results, it can be concluded that Managerial Ownership has no significant effect on CSR so that managerial ownership does not have harmony between owners and managers. Institutional ownership does not significantly affect CSR, so that ownership owned by this institution is still aimed at personal interests rather than outside interests. Foreign ownership has a significant effect on CSR. This shows that foreign investors have a concern for outside interests. Earning Management does not significantly affect CSR. This is because management has different considerations in presenting their financial information, and together the independent variables have a simultaneous influence on the dependent variable. This means that any changes that occur in Managerial Ownership, Institutional Ownership, Foreign Ownership and Earnings Management will jointly affect CSR.

\section{REFERENCES}

[1]. Anggraini, Fr. Reni Retno. "Pengungkapan Informasi Sosial dan Faktor faktor yang Mempengaruhi Pengungkapan Informasi Sosial dalam Laporan Tahunan". Makalah disampaikan pada Simposium Nasional Akuntansi IX. Padang, 2006, 23-26 August.

[2]. Barkemeyer, R. Legitimacy as a key driver and determinant of CSR in developing countries. Paper for the 2007 Marie Curie Summer School on Earth System Governance, Amsterdam.I.S. Jacobs and C.P. Bean, "Fine particles, thin films and exchange anisotropy," in Magnetism, vol. III, G.T. Rado and H. Suhl, Eds. New York: Academic, 1963, 2007, pp. 271-350.

[3]. Chih, H.L, Shen, C.H \& Kang, F.C. Corporate Social Responsibility, Investor protection, and Earning Management: Some International Evidence. Journal of Business Ethic, Vol. 79, 2008, pp.179-198.

[4]. Faizal. Analisis agency costs, struktur kepemilikan dan mekanisme corporate governance. Simposium Nasional Akuntansi VII Denpasar Bali, 2004, pp.197207.

[5]. Ghozali, \& Chariri. Teori Akuntansi. Penerbit Universitas Diponegoro, 2007, Semarang.

[6]. Hendrik, Budi Untung. Corporate Social Responsibility. Jakarta, 2008, Sinar Grafika.

[7]. Suharto, Edi. Membangun Masyarakat Memberdayakan Masyarakat. Bandung, 2009, PT Refika Aditama.

[8]. Lobo, Gerald J, Zhou.Disclosure Quality and Earnings Management. Social Science Electronic Network Paper Collection, May 2001.

[9]. Merchant, K.A. \& Rockness, J. The Ethics of Managing Earnings: an Empirical Investigation, 1994, Journal of Accounting And Economics.
[10]. Mursalim. "Simultanitas aktivisme institutional. struktur kepemilikan. Kebijakan deviden dan hutang dalam mengurangi konflik keagenan." Simposium Nasional Akuntansi 10, 2007, Makasar.

[11]. Nasir, Moch. N.A \& Abdullah, S.N. "Voluntary Disclosure and Corporate Governance among Financially Distressed Firms in Malaysia”. Financial Reporting, Regulation and Governance, 2004, Vol. 3 No. 1.

[12]. O'Donovan. "Environmental Disclosure in the Annual Report: Extending the Applicability and Predictive Power of Legitimacy Theory", Accounting, Auditing and Accountability Journal, Vol.15, No.3, 2002, pp.344-371.

[13]. Prior. "Earnings Management and Corporate Social Responsibility Disclosure", 2010, Economic Journal of Universidad Carlos III de Mardid.

[14]. Ratnasari, Ririn Tri \& Mastuti H. Aksa. Manajemen Pemasaran Jasa. Bogor, 2010, Ghalia Indonesia.

[15]. Rawi \& Munawar Muchlish. "Kepemilikan Manajemen, Kepemilikan Institusi, Leverage dan Corporate Social Responsibility". Makalah disampaikan pada Simposium Nasional Akuntansi XII, 2010, Puwokerto.

[16]. Rosmasita, Hardhina. "Faktor-faktor yang mempengaruhi pengungkapan sosial (Social Disclosure) dalam Laporan Keuangan Tahunan Perusahaan Manufaktur di Bursa Efek Jakarta”. Makalah disampaikan pada Simposium Nasional Akuntansi X, 2007, Makasar.

[17]. Rustiarini, Ni Wayan. "Pengaruh Struktur Kepemilikan Saham Pada Pengungkapan Corporate Social Responsibility”, 2008, Simposium Nasional Akuntansi.

[18]. Tarjo. Pengaruh Konsentrasi Kepemilikan Institusional dan Leverage Terhadap Manajemen Laba, Nilai Pemegang saham serta Cost of Equity, 2008.

[19]. Zarkasyi, Moh. Wahyudin. Good Corporate Governance: pada Badan Usaha Manufaktur, Perbankan, dan Jasa Keuangan Lainnya. Bandung, 2008, Alfabeta. 